without a single drawback, the membrane quickly disappearing from all the situations mentioned. I feared greatly that the cornex would be destroyed, but this fortunately did not take place and the eyes have quite recovered. About a fortnight ago I had the secretions from the mouth and throat examined by the Clinical Research Association and no KlebsLöfller bacilli could be found. There has so far been no sign of post-diphtheritic paralysis and the patient is now at the - zeaside and in excellent health. A curious point is that he sad diphtheria six years ago. I venture to quote this case aecause of the unusual number of mucous membranes simultaneously involved and to show the rapidly curative effect of the anti-diphtheritic serum in a case more than ordinarily virulent.

Beverley.

\section{EXPULSION OF ENTIRE UTERINE CONTENTS A'T THE SEVENTH MONTH.}

BY W. F. Gardener, M.R.C.S. Eng., L.R.C.P. LoND.

THE patient was a married woman, aged thirty-five years, a multipara. At the time of her delivery she was in the last stage of pulmonary phthisis, unable to lie down at all and greatly emaciated. She was seen on the morning of the day of her confinement and had then no pains. During the aftermoon she sent for the nurse whom she had engaged to attend her during her confinement as she "felt her pains coming on." The nurse found these to be slight and infrequent and left her with instructions to send again if they did not leave her. In the evening she sent for the nurse again, shortly after whose arrival the pains became suddenly strong, and with two or three violent straining efforts the child, contained in the membranes, with the placenta, was suddenly rextruded into the bed. On my arrival I found the uterine contents left in situ as they had been born. I immediately ruptured the membranes, but there was no move:ment of the child, which had apparently been dead for some hours. The uterus was firmly contracted and there was no further hæmorrhage. Of this there had been a slight amount at the birth but none whatever previously. The patient died during the following night. If the uterine contents were absolutely untouched, as the nurse asserted, there was not placenta prævia, as, judging from the position on the bed, the placenta came last.

Sydenham, S.E.

\section{PRIMARY MENSTRUATION AND FIRST PREGNANCY IN MIDDLE LIFE.}

BY J. F. WOLFE, M.B. EDIN.

THE following case deserves to be recorded on account of the great rarity of similar phenomena. A married woman, aged forty-five years, menstruated for the first time about reighteen months ago. When about nineteen years of age she was treated for amenorrhca at the Portsmouth Hospital for a period of three or four months, but never had the slightest symptom or sign of menstruation until when in her forty. chird year she was seriously frightened by an idiot (a stepdaughter living in the same house). Menstruation thereupon commenced on the same day and lasted two or three days, from which time up to the date of impregnation, she menstruated but a few times and not at all regularly. The labour, which came on at full term of pregnancy, was much shorter than might have been expected, lasting not more than thirteen hours; the presentation was left occipito-anterior; the pelvis was roomy; forceps were not required. There was apparently nothing unusual about the external genitals, the mammæ were fairly well dereloped, and milk came freely on the third day. The patient has had seven brothers and two sisters, all of whom diee under five years of age. She herself (the youngest) never had any serious illness, but is rather anæmic and has suffered from frequent headaches (not periodically) which do not appear to have lessened in frequency or severity since menstruation started. She has been married eleven years, her husband is healthy and has been living with her all the time. He had seven children by his first wife, all of whom are alive and healthy with the exception of the one above mentioned. For permission to publish this case, which as far as $\mathbf{I}$ can ascertain is unique, $\overline{\mathbf{I}}$ am indebted to $\mathbf{M r} . \mathrm{H}$. $\mathbf{P}$. Gaston of Southsea, for whom I attended the patient.

Portsea.

\section{d eftitror

\author{
OF
}

\section{HOSPITAL PRACTICE, BRITISH AND FOREIGN.}

Nulla autem est alia pro certo noscendi via, nisi quamplurimas et morborum et dissectionum historias, tum aliorum tum proprias collectas habere, et inter se comparare.-MoRgaGrI De Sed. et Caus. Morb., lib. iv. Procmium.

\section{ROYAL FREE HOSPITAL.}

A CASE OF EXTREME COLLAPSE TREATED ON THREF OCCASIONS BY THE INTRAVENOUS INJECTION OF SALINE SOLUTION.

(Under the care of Mr. BoYCE BARRow.)

THE treatment to be adopted in cases of severe shock depends mostly on the cause which has given rise to it and the use of intravenous injection of fluid is practically chiefly of value in those cases in which a large amount of blood has been lost. Although occasionally success followed the transfusion of blood and the intravenous injection of milk. yet the results of these methods of treatment were on the whole very unsatisfactory. Even the employment of defibrinated blood as recommended by Panum of Copenhagen in 1863 was no more successful, and the operation was generally followed by a rise of temperature, possibly due, as explained by some, to fibrin ferment which had been set free in the process of whipping. The use of saline injections into the veins has now entirely replaced all other forms of transfusion. Many complex mixtures of various salts are recommended, but they take time to prepare and there is no evidence that the results following their use are any better than may be obtained by employing a simple solution of common salt of the strength of 1 drachm to the pint. The more extensive present use of the intravenous injection of saline solutions is in great measure due to the advocacy of this method by Dr. William Hunter in 1889. For the notes of this case we are indebted to Mr. Reginald Hayes, late house surgeon.

A delicate boy, fourteen years of age, who was suffering from cleft palate, was admitted to the Royal Free Hospital in January, 1897, with sinuses of the hip which had troubled him for nearly two years and for which some half-dozen operations had been performed elsewhere. For six months he had worn a Thomas's splint and during the past four weeks abscesses had formed in and around his right groin for which he had been treated at the local infirmary. An examination of the hip made it evident that there was a considerable amount of disease and in a week's time he was anæsthetised with chloroform (which was soon changed for ether) with a view to a more thorough investigation of his condition being made. He lost a good deal of blood in consequence of the considerable amount of fibrous tissue in which some large vessels were embedded making it difficult to secure them rapidly. Extensive disease of the pelvis, great trochanter, and upper third of the femur was found, a good deal of carious bone being removed and the cavity being finally packed with bicyanide gauze. Towards the close of the operation the patient's pulse became so feeble that brandy and strychnine were injected subcutaneously and an enema of hot port wine was administered while he was in the theatre. On removal to the ward his legs and arms were enveloped in cotton wool and were bandaged from the extremities upwards; the foot of the bed was raised and the patient was surrounded with warm-water bottles. Nutrient enemata with brandy were ordered to be administered every three hours as vomiting was troublesome, but as his condition got gradually worse, the temperature falling to $96^{\circ} \mathrm{F}$. and the pulse becoming feebler and of a running character and all ordinary methods having failed, at 10 P.M. (sir hours after the operation) over two pints of normal saliue solution at $100^{\circ}$ were injected into the left median basilic vein. Marked improrement was apparent for a couple of hours, when the patient became unconscious, with pupils widely dilated, the pulse imperceptible at the wrist and Cheyne-Stokes breathing. He was now apparently moribund, so it was decided again to try transfusion. The right median basilic rein wes found 
with some difficulty and over three pints of the saline solution were injected. Towards the end of the injection of the third pint improvement was very obvious; he recovered consciousness and attempted to sit up in bed, smiling and mentioning that he "felt better." The radial pulse became perceptible and of fair volume. He shortly afterwards fell into a sleep which lasted for over five hours and though for several days his condition remained critical he eventually made a good recovery. In about five months time, after a couple of thorough examinations under anæsthetics had been made, Mr. Barrow decided that in consequence of the amount of disease in the pelvic and thigh bones, and taking into consideration the patient's general condition, amputation at the hip-joint would afford him the best chance for his life. This was performed by a modification of the Furneaux Jordan method. Some difficulty was experienced in securing the common femoral artery, which was partially embedded in fibrous tissue and firmly attached to the bone. At this point a good deal of blood was lost. Towards the end the pulse became weak and running and profuse perspiration occurred. On removal to bed the patient became more collapsed; the temperature fell to $95^{\circ}$ and the pulse was 146 and grew more and more feeble till it was scarcely perceptible. All the ordinary treatment of shock was tried without any improvement and the patient appeared to be sinking rapidly. Accordingly about 8.30 P.M. two pints of saline solution were injected into the right median cephalic vein, with the result that the temperature gradually rose to normal, and though his condition gave cause for anxiety for several days the lad ultimately made a good recovery. After a few weeks in a convalescent home he returned in the following month, looking very well, in order to have his cleft palate operated on, which was done with a successful result.

Remarks by Mr. ReGINALD HAYES.-The case is interesting as showing the striking manner in which this patient reacted to the transfusion with saline solution after failure of the ordinary lines of treatment; and the effect of the second injection after the first operation, when from a moribund condition he recovered sufficiently to smile and speak, attempting to sit up in bed, was very remarkable.

\section{ADDENBROOKE'S HOSPITAL, CAMBRIDGE.}

TWO CASES OF DISEASE OF THE SPINAL CORD FOLLOWING PREGNANCY AND LABOUR.

(Under the care of Dr. J. B. BradBury.)

THoUGH there are not wanting arguments in favour of the presence in the blood of toxic substances during pregnancy, and though this theory would serve to explain readily some conditions, such as the nephritis of pregnancy, which are not susceptible otherwise of any easy explanation, yet it must be admitted that in the vast majority of pregnancies there is no evidence of any toxins. The two cases which follow are well worthy of being placed on record, for they are very suggestive of some causal connexion between the pregnancy and the lesion of the spinal cord, though it would be rash to say that one was certainly due to the other. For the notes of the cases we are indebted to Dr. Francis Villy, house physician, and Dr. Burton, late house physician.

CASE 1.-A married woman, aged forty-three years, was admitted into Addenbrooke's Hospitál on Sept. 21st, 1896. There was no family history of nervous disease or history of syphilis. The patient had been the mother of eighteen children and had had two miscarriages. Her health had been good till seven years before admission, when she gave birth to a hydrocephalic child. Pain and weakness across the loins followed this event and lasted for nine months; in a year from the same date she lost the use of the right arm and leg suddenly, no loss of consciousness or other cerebral symptoms occurring. There was no facial paralysis or alteration of sensation. About ten months before admission she began to have severe sacral pain; in five months pain occurred in the left knee also, and from that time she began to lose power in the left leg. The sphincters were never affected. On admission the right arm was weak without alteration of sensation or wasting; the reflexes were lively. The left arm was not affected. Both lower limbs were partially paralysed without alteration of sensation, the right one being more advanced than the left, which was slightly wasted. The knee-jerk was much exaggerated and ankle clonus was well marked on the right side; the left leo was normal in these points. Both legs underwent spasms of rigidity at times. No cranial nerves were affected. Subsequently cramp-like pains occurred in both legs and ankle clonus developed on the left side. A feeling of constriction round the abdomen also occurred but did not amount to a definite girdle pain. Under physostigmine the subjectire symptoms improved considerably, though the physical sigr:s were still present at the date of the patient's discharge from the hospital (Nov. 15th, 1896).

CASE 2. - A married woman, aged thirty-seven years. was admitted to Addenbrooke's Hospital on Dec. 299th, 1897. There was no family history of nervous disease. She had never enjoyed good health, but there was no history of previous disease except the occurrence of an ulcer of the stomach eighteen years previously. She was the mother of ten children and dated her present illness from her last confinement seven months before admission. She had had sacral pain ever since that event and had never been able to walk properly subsequently, though there had previously been no such difficulty. For three months the legs had beein numb, though there had been a deep aching pain throughout their extent for some time. On admission the cranial nerres and the arms were normal. The sensations of touch, temperature, and pain were diminished almost up to the unbilicus, though they were not abolished completely. Th\% distribution of this altered sensation was not regular, tactile sensation being fairly well developed at a zone round eack knee and in the feet. Loss of sensation of temperature was most marked. The plantar reflexes were normal, both knee-jerks were much exaggerated, and well-marked ankle clonus was present on each side. The muscular power of the legs was good, no reaction of degeneration being discorered. The patient stated that her legs bad wasted slightly during her illness; they were constantly in a spastic condition. The symptoms became steadily worse in spite of treatment and the patient was discharged from the hospital on March 12 th 1898, in a distinctly less favourable condition than on her admission.

Remarks by Dr. VILLX.-The symptoms of lesion of the: spinal cord were in each of the above cases so marked and followed so closely after labour that a relation of effect and cause between the two occurrences suggests itself very strongly. Such a relation does not seem to be improbable a priori, for it has long been recognised that pregnancy (apart from any septic change due to labour) is a not very uncommon cause of peripheral neuritis. ${ }^{\text {I }}$ Moreover, there are many who believe that in normal pregnancy there is a general toxic state $^{2}$ and such a toxæmia is a recognised precursor of certain diseases of the central nervous system; for instance. syphilis, typhus fever, influenza and other similar diseases may precede lesions of the central nervous system. I can find very little recorded of the production of such diseases by pregnancy. Sir William Gowers ${ }^{3}$ mentions that primary spastic paraplegia has in several cases succeeded prostration after childbirth or abortion, or has commenced durins lactation, but he gives no further account of such cases. Turney ${ }^{4}$ mentions a patient in whom anterior poliomyelitis followed about a month after labour. To prove that the nervous lesions in the two cases in question were actually caused by pregnancy or labour would be a very difficult matter, for not only would it be necessary for such $\approx$ purpose to exclude the recognised antecedents of similas diseases, but it must also be shown that mere coincidence has not simulated cause and effect. Though much more extended observations than the present ones would be necessary to exclude this last possibility, yet the cases seem: to be sufficiently striking to suggest more than coincidence. and it is hoped that this note may serve at least to dran attention to the subject. It will be noticed that in eacl of the above cases the period of onset followed a cor.. siderable time after labour, a course which is at least unusual in peripheral neuritis. In both instances the symptoms were chiefly those of lateral sclerosis, thongh plainly the lesion was not of the pure form of that disease.

1 Reynolds : Brit. Med. Jour., Oct. 16th, 1897. Turney: St. Thomas's Hospital Reports, vol. xxv. 2 Clifford Allbutt: THE LANCET, Feb. 27th, 1897.

3 Diseases of the Nervous Systems, second edition, vol. i., p. 443, 